\title{
POST-KONSTITUSIONELE REGSPRAAK OOR DIE WYSIGING VAN DISKRIMINERENDE BEPALINGS IN TESTAMENTÊRE TRUSTS MET 'N LIEFDADIGHEIDSOOGMERK
}

\author{
Henda Steyn* \\ University of the Free State \\ SteynH@ufs.ac.za
}

Received: June 2015

Accepted: October 2015

\begin{abstract}
Abstrak
Die testamentêre trust as sui generis regsfiguur speel 'n belangrike sosiale rol in die Suid-Afrikaanse reg. Die gewildheid van hierdie instelling as boedelbeplanning meganisme het aansienlik toegeneem, deels as gevolg van die beskerming wat aan die testateur se afhanklikes gebied word en deels as gevolg van die eenvoudige, dog doeltreffende praktiese werking daarvan. Een van die groot voordele van ' $n$ Testamentêre trust is die gemak waarmee ' $n$ erflater se wense, soos vervat in sy/haar testament, geïnterpreteer en geïmplementeer kan word. Daar is in ons reg ' $n$ besliste wisselwerking tussen die erfreg en die trustreg van toepassing op testamentêre trusts. Die beginsel van testeervryheid is ' $n$ konsep wat in die Suid-Afrikaanse reg met die nodige respek behandel word en alhoewel dit onderhewig is aan sekere gemeenregtelike en statutêre beperkings, is die aanvaarde siening dat daar effek gegee sal word aan die wense van ' $n$ testateur soos uitgedruk in sy / haar testament. Die bestaande politieke en sosiale omgewing in Suid-Afrika, soos wat onderskryf en vervat word in die Grondwet van die Republiek van Suid-Afrika (hierna verwys as die Grondwet), plaas egter ' $n$ groter beperking op die reg op individuele testeervryheid. Die huidige tendens bestaan dat indien ' $n$ Testamentêre trust geskep word en ' $n$ openbare instelling soos ' $n$ universiteit betrokke is, die testamentêre trust gewysig sal word indien enige van die bepalings daarin vervat geklassifiseer kan word as om diskriminerend van aard te wees. Hierdie artikel fokus op die evaluering van die ratio decidendi van die howe in onlangse hofuitsprake. Dit sal die neiging beklemtoon dat al die howe van dieselfde mening is dat die sogenaamde "diskriminerende bepalings" in testamentêre trusts met 'n liefdadigheidsoogmerk gewysig moet word, maar dat die howe se interpretasie van die feite met betrekking tot die verskillende toepaslike areas in ons reg wissel van geval tot geval. Dit sal duidelik aantoon dat die tyd aangebreek het vir' $n$ spesifieke stel reëls, wat konsekwent toegepas kan word - 'n grondwetlik gebaseer boni mores kriteria om eenvormigheid en regverdigheid te verseker, en dat die huidige status quo nie aanvaarbaar is, slegs omdat dit die gewenste resultate lewer nie.
\end{abstract}

\section{Sleutelwoorde}

Grondwet van die Republiek van Suid-Afrika, 1996, ratio decidendi, testamentêre trusts, onregverdige diskriminasie, testeervryheid, openbare beleid, liefdadigheidsoogmerk 


\title{
An analysis of post-constitutional case law relevant to the amendments of discriminatory provisions in charitable testamentary trusts
}

\begin{abstract}
The testamentary trust as sui generis legal figure plays an important social function in South African law. The popularity of this institution as estate planning mechanism has increased considerably, partly because of the protection given to the testator's dependants and partly because of the simple, yet effective, practical working of it. One of the major benefits of a testamentary trust is the ease with which a testator's wishes, as contained in his/her will, can be interpreted and implemented. The Charitable testamentary trust has even more unique characteristics and due to its aim - a charitable intent, it has the effect that South African courts are struggling to reconcile the different elements of existing legal principles in amending these types of trusts. It is the generally excepted approach that charitable testamentary trust will not summarily be declared invalid if the trust purpose or beneficiaries are not clearly defined. Our courts have a certain amount of freedom of interpretationalthough not absolute - in these cases and they can look at the facts of each case to determine the aim of the trust. (Corbet at al., 2001:430)
\end{abstract}

The charitable testamentary trust has a trifecta of legal fields relevant to govern it. There is a close interaction between the law of succession and the law of trusts applicable to testamentary trusts as well as some common law principles that must be applied.

The Concept of Freedom of Testation in South African law, can be briefly summarized to mean that an individual has the freedom to execute a will, the power to determine in his will how his assets must be divided and to nominate the persons that will receive the benefits after his death and to choose to make these bequests subject to certain conditions. The importance of the protection of individual freedom of testation is repeatedly confirmed in our legal system and is treated in our courts with the necessary respect. Although South Africa has a very liberal approach to freedom of testation, it is not absolute and is limited by certain common law and statutory restrictions - the most important restriction for purposes of this article is of course that effect cannot be given to a bequest that is $A$ bequest that is impracticable / vague / unclear, unlawfully / illegally or contrary to good morals (contra bonis mores), impossible, or contrary to the principles of public interest.

The existing political and social environment in South Africa, as supported and endorsed by the principles embodied in the Constitution of the Republic of South Africa (hereinafter referred to as the Constitution), however, is resulting in a greater limitation on individual freedom of testation. The current trend is that if a testamentary trust is created and a public institution, such as a university is involved, the testamentary trust will be amended if any of the provisions contained therein can be classified as discriminatory. As a university is considered to be a 'public agency or quasi-public body, (Syfrets, 2006:par 45-45) there rests a greater responsibility on them to promote the principle of public interest and that the provisions to which they are measured in terms of discriminatory behaviour, are more stringent than for private individuals. (Du Toit, 2001:255).

This article will focus on the evaluation of the ratio decidendi of the court's judgments in recent court cases.

In the Ministers of Education v Syfrets Trust in 2006 (4) SA 205 (K) - the first of its kind in a postconstitutional South Africa - the testamentary trust came into being in 1969. This trust reserved benefits for individuals of 'European descent only' and excluded any Jewish of Female Applicants from receiving any benefits. It was determined that the discrimination in this case was unfair on the grounds of race, religion and gender and that the discriminatory clauses must be deleted. The judge decided the matter on the common law requirement that bequests cannot be against public policy. And 
although the judge might have exceeded the public-policy based common-law exception to the nonvariation rule by stating that a complete clause in the will should be deleted. The desired result was achieved by the removal of the unfair discriminatory clauses. In subsequent cases, University of KwaZulu-Natal v Makgoba and Others (17124/2005) [2009] ZAKZDHC 28 (July 17) and the betterknown subsequent appeal curators, Emma Smith Educational Fund v University of KwaZulu-Natal in 2010 (6) SA 518 (SCA) and IN Re Heydenrych Testamentary Trust and Others 2012 (4) SA 103 (CHP), the decision is based on the application of Article 13 (a) and (c) of the Trust Property Control Act, 57 of 1988. This section determines that if a trust instrument contains any provision which brings about consequences which in the opinion of the court the founder of a trust did not contemplate or foresee and which - hampers the achievement of the objects of the founder, or prejudices the interest of beneficiaries or is in conflict with public interest, the court may, delete of vary any such provision or make in respect thereof any order which such court deems just. In these above mentioned cases there was clear unfair discrimination, on grounds such as race, gender and religion, but what is important to take note of is the fact that at the time these charitable testamentary trusts came into being, the clauses in it was not seen as discriminatory or against public interest. Public interest is a changing concept, but, as with the law of contracts, should be applied in the current time with the current definition of public benefit.

In the case Ex Parte BOE Trusts Ltd 2009 (6) SA 470 (CHP) and In Re BOE Trust Ltd and others NNO 2013 (3) SA 236 (SCA) the will was drafted in 2002, the testatrix in this case, was aware that the clause in the will that stated the bursary should only benefit white students, would be seen as discriminatory. She therefore added an alternative clause to state that if effect cannot be given to the original clause, the benefit must go to 10 charitable institutions. It was the intention of the testatrix in this case to benefit white students to further their studies overseas, but after the completion thereof, they have to come back to South-Africa to work here for a term of 5 years. The intention of the testatrix was not to discriminate in the true sense of the term, but to counteract the "brain drain" in this specific field of study. In this case, the court ordered not to change or delete the clause in the trusteed that was deemed to be discriminatory, but to give effect to the alternative clause introduced in the trust deed because of the fact that the University did not want to administer the trust and it therefore became impossible to achieve the object as originally intended. This is clearly a small step forward in developing this field of our law through case law - to look at a testator's intention.

It is the current accepted situation that the courts are of the same opinion that so-called "discriminatory provisions" should be amended, but the interpretation of the facts on applicable areas of our law varies from case to case.

It stands therefore clear that our law is ripe for the introduction of a specific set of rules - a constitutionally-based boni mores criteria, (Du Toit, 2012:165) that must be consequently applied to ensure fairness and consistency, and that the current status quo is not acceptable just because it achieves the desired results.

\section{Keywords}

Constitution of the Republic of South Africa, 1996, ratio decidendi, testamentary trust, unfair discrimination, freedom of testation, public benefit, charitable aim

*Ms H Steyn is a lecturer in the Faculty of Law, University of the Free State, Bloemfontein, South Africa. 


\section{INLEIDING}

Die Grondwet van die Republiek van Suid-Afrika, 1996 (hierna die Grondwet) word geag die oppergesag in ons land te wees en die geldigheid van enige statutêre of gemeenregtelike reëls word gevolglik aan die objektiewe en normatiewe waardes wat in hierdie wet verskans is, gemeet. Die algemene aanvaarde siening is dat Suid-Afrika se Grondwet baanbrekerswerk gedoen het om 'n nasie te skep wat menseregte primêr stel deur individuele vryheid en gelykheid te waarborg. Die Grondwet het ook die effek dat sekere terme soos openbare beleid en onregverdige diskriminasie, statutêr verwoord is, en dat daar sekere regte daarmee of beskerming daarteen gewaarborg word.

Die juriste se besprekings en opinies sowel as die howe se hantering van diskriminerende bepalings in testamentêre trusts gaan krities geanaliseer word deur volledige besprekings van die ratio decidendivan onlangse hofsake. In elk van die sake wat bespreek word, het die howe gelas dat diskriminerende bepalings in die betrokke testamentêre trusts gewysig moet word. In elk van die verskillende hofsake word gefokus op die rasionaal wat die howe toegepas het om die fundamentele grondwetlike reg tot gelykheid en vryheid van onregverdige diskriminasie met die fundamentele grondwetlike waarborg tot private eienaarskap, wat individuele testeervryheid insluit, te vereenselwig.

Deur die interpretasie van hierdie kompeterende grondwetlike waarborge in regspraak, word daar bepaal of die effek wat dit op die trustreg, erfreg en die gemenereg het, konsekwent toegepas word. Die huidige interpretasie en uitbreiding van die toepassing van die beginsel van openbare belang sal in elke hofsaak geïllustreer word om te bepaal of dit gegrond is op suiwer judisiële beginsels en of die howe tans besig is met judisiële aktivisme en sodoende hul onpartydige status te verloor. Deur staat te maak op die toepassing van die beginsel van openbare belang, bemagtig die howe hulself om 'n beperking te plaas op individuele testeervryheid en om hul magte ten opsigte van die wysigings van testamentêre trusts te verbreed.

In hierdie artikel gaan daar deur die analise van uitsprake getoon word dat die howe, in regspraak in 'n post-konstitusionele era, besig is om elke saak ad hoc op sy eie meriete te beoordeel. Die howe is tans nie besig om deur hul uitsprake' $n$ universele stelreël te ontwikkel wat op aanvaarde en geldige regsbeginsels gegrond is nie.

\section{REGSPRAAK OOR DIE WYSIGING VAN DISKRIMINERENDE BEPALINGS}

In al die sake wat bespreek word, is daar grootliks op dieselfde gronde gesteun, maar die interpretasie hiervan het in sommige gevalle drasties verskil.

In Minister of Education v Syfrets Trust 2006 (4) SA 205 (K) - die eerste van hierdie aard in ' $n$ postkonstitusionele Suid-Afrika - het die regter die saak beslis op die gemeenregtelike bepaling dat testamentêre bepalings nie teen openbare belang kan wees nie. In die opvolgende sake, University of KwaZulu-Natal v Makgoba and Others (17124/2005) [2009] ZAKZDHC 28 (17 Julie) en die meer bekende daaropvolgende appèlsaak Curators, Emma Smith Educational Fund v University of KwaZulu-Natal 2010 (6)SA 518 (HHA) asook IN Re Heydenrych Testamentary Trust and Others 2012 (4) SA 103 (WKK) het die beslissing berus op die toepassing van artikel 13(a) en (c) van die Wet op die Beheer oor Trustgoed, 57 van 1988. Die sake wat 'n duidelike verandering in die hof se benadering tot stand gebring het, was EX Parte BOE Trusts LTD 2009 (6) SA 470 (WKK) en In Re BOE Trust LTD and others NNO 2013 (3) SA 236 (HHA). In hierdie saak het die hof gelas om nie enige wysigings of skrappings aan die trustakte te gelas nie, maar om uitvoering te gee aan die 
alternatiewe klousule wat in die trustakte aangebring is as gevolg van die onuitvoerbaarheid van die oorspronklike "diskriminerende" bepaling.

Waarop deurentyd klem gelê sal word in die volledige bespreking wat gaan volg, is hoe die howe die balans gehandhaaf het tussen die grondwetlike reg op testeervryheid soos omskryf in artikel 25(1) van die Grondwet en die verbod op enige vorm van direkte of indirekte diskriminasie soos omskryf in artikel 9 van die Grondwet, en interpretasie in elke saak van die terme diskriminasie, redelike diskriminasie, openbare beleid en die spesifieke verantwoordelikheid wat openbare instansies het om nie aan enige mate van diskriminerende gedrag deel te neem nie. Die toepassing van die statutêre reg tot wysiging, soos verleen in artikel 13 van die Wet op die Beheer oor Trustgoed (Republiek van Suid-Afrika, 1988), word ook bespreek.

\subsection{Minister of Education v Syfrets Trust 2006 (4) SA 205 (K)}

\subsubsection{Agtergrond}

Dr. Edmund William Scarbrow (die testateur) het op 23 April 1920 'n testament opgestel waarin hy bepaal het dat indien sy vrou en albei sy seuns sou sterf sonder om enige wettige afstammelinge na te laat, die restant van sy boedel in trust geplaas en aangewend moet word vir die skep van beurse vir arm studente van beide geslagte, maar slegs vir Europese afstammelinge - dus, slegs vir blanke studente.

Op 2 Desember 1920 het dr. Scarbrow 'n addisionele kodisil bygevoeg wat verdere beperkings geplaas het op die kriteria vir die bepaling van geskikte kandidate, naamlik dat alle vroulike persone van alle nasionaliteite en ook alle persone van Joodse afkoms daarvan uitgesluit is om ' $n$ voordeel te ontvang ingevolge hierdie bemaking.

Die testateur is op 7 Julie 1921 oorlede en sy twee seuns is, sonder om enige wettige afstammelinge na te laat, onderskeidelik in 1953 en in 1965 oorlede. Dit het tot gevolg gehad dat die Scarbrow Beursfonds op die been gebring is. Die Raad van die Universiteit van Kaapstad het egter in 1969 besluit dat as gevolg van die diskriminerende bepalings in die testament, hulle nie die administrasie van hierdie beurse kan hanteer nie. Gevolglik is die administrasie van hierdie beurse deur Syfrets in sy hoedanigheid as trustee van hierdie trust hanteer.

In Maart 2002 het 'n advertensie wat voornemende studente uitnooi om aansoek te doen vir hierdie beurs onder die aandag van die Minister van Onderwys gekom. Die Minister het ' $n$ brief aan Syfrets gerig om te versoek dat hierdie beperkende bepalings uitgesluit word in die lig van die reg op gelykheid soos wat in die Handves van Menseregte gewaarborg word. Syfrets het egter aangevoer dat die beginsel van individuele testeervryheid hulle verbied om af te wyk van die wense van die testateur soos wat vervat is in sy testament en dat hulle die bepaling slegs kan wysig indien hul'n bevel van die hooggeregshof kry wat so 'n wysiging magtig. Die Minister van Onderwys (applikant) het toe die hof genader vir 'n bevel om die diskriminerende bepalings wat in hierdie testament vervat is, te skrap.

Die hof het in sy beslissing op die bepalings in die gemenereg wat bemakings verbied wat onwettig, immoreel of teen openbare belang is, gesteun en dienooreenkomstig beslis dat die woorde "but of European descent only" soos vervat in klousule 4(d) van die testament, gedateer 23 April 1920, geskrap moet word, en dat die kodisil gedateer 2 Desember 1920 in sy totaliteit geskrap moet word. 
Die testamentêre bepalings word geag onregverdige diskriminasie te wees en moet ingevolge die gemenereg verwyder word. Die howe het nie met hierdie beslissing die beginsel van testeervryheid geïgnoreer nie, maar slegs beperk.

\subsubsection{Testeervryheid en balans}

In die saak is aangevoer dat artikel 25(1) van die Grondwet, wat die reg aan jou verleen om met jou eiendom tydens jou lewe te handel soos jy behaag, dus die reg insluit om testamentêr oor jou eiendom te beskik en waarborg sodoende individuele testeervryheid (Currie et al., 2005:531-534).

Die regter het egter beslis dat dit'n te wye interpretasie van hierdie artikel is. Artikel 25(1) van die Grondwet beskerm teen willekeurige (arbitrêre) ontneming van eiendom en die verwydering van die spesifieke bepalings uit die testament voldoen nie aan hierdie definisie nie. Dit is ook'n algemeen aanvaarde beginsel dat testeervryheid nie absoluut in Suid-Afrika is nie en ongeag die liberale toepassing van hierdie beginsel in ons reg, is daar steeds beperkings op testeervryheid.

Die testateur het tydens sy lewe volle beheer oor sy eiendom gehad en dit toe met sy dood aan 'n testamentêre trust bemaak. Die wysiging van 'n bepaling in hierdie trustakte maak nie inbreuk op hierdie reg wat hy gehad het nie, dit het slegs die effek dat die bestaande trustakte gewysig is om 'n bepaling te verwyder wat teen openbare beleid geag word. Die howe het al voorheen wysigings aan testamentêre trusts aangebring op grond van openbare beleid, noodsaaklikheid of onmoontlikheid sonder dat daar aangevoer is dat die trusts van eiendom ontneem word.

Die bepaling stipuleer ook dat beskerming gewaarborg word op grond van die arbitrêre ontneming. Vir 'n ontneming om geag te word arbitrêr te wees, moet dit prosedureel onregverdig of sonder rede plaasvind. Dit sal ook nie slaag nie, want die hof reik 'n bevel uit om die wysiging te implementeer na'n volledige oorweging van al die feite.

\subsubsection{Staatsinstellings}

Wat ook van uiterste belang is, is dat die Universiteit geag word om 'n staatsinstelling te wees, ' $a$ public agency or quasi-public body' (Syfrets, 2006:par 45-45). Dit beteken dat daar 'n groter verantwoordelikheid op staatsinstellings rus om die beginsel van openbare belang te bevorder en dat die bepalings waaraan hulle gemeet word ingevolge diskriminerende optrede, strenger is as vir privaat individue.

\subsubsection{Openbare beleid en onbillike diskriminasie}

In die saak is beklemtoon dat openbare beleid nie staties is nie, maar dat dit verander en aanpas by die sosiale omstandighede van 'n spesifieke era en ook dat die terme openbare belang, openbare beleid, boni mores en die algemene sin van geregtigheid in die gemeenskap as sinonieme geag kan word (Syfrets, 2006:par 23-25).

Die belangrikheid van die beginsel van openbare belang is duidelik te bespeur in die fundamentele waardes soos vervat in die Grondwet, maar dat openbare belang, net soos met kontraktereg, geïnterpreteer word in die tydperk wanneer daar uitvoering daaraan gegee moet word (Kruger, 2011:par 712-740).

Dus, toe hierdie testament in 1920 opgestel is, was die betrokke bepalings nie teen die openbare belang soos wat dit geïnterpreteer was in daardie tyd nie, maar dit is wel teen die beginsel van openbare belang in die huidige bedeling in Suid-Afrika. Die regter het beslis dat in hierdie 
testament daar bepalings is wat as direkte diskriminasie sowel as indirekte diskriminasie geklassifiseer kan word. Die uitsluiting van Jode en vroue, ingevolge die kodisil, is direkte diskriminasie op grond van geloof en geslag en die beperking van die beurs tot kandidate van 'Europese afkoms' sal as indirekte diskriminasie op grond van ras geklassifiseer word.

Die hof het beslis dat die diskriminasie in hierdie geval, beide direk en indirek, onregverdig was, omrede:

- die persone waarteen gediskrimineer word deel uitmaak van groepe waarteen in die verlede onder die apartheidsregime gediskrimineer is, naamlik swartmense, vroue en Jode;

- die bewoording van hierdie bepalings die marginalisering van hierdie groepe (par (b)) vererger deur ' $n$ spesifieke geloof van die voordeel uit te sluit;

- die bemakings geag word kan om teenstrydig te wees met bestaande nasionale wetgewing (National Education Policy South Africa, 1996: artikel 29) asook teen internasionale konvensies en standaarde ten opsigte van diskriminasie.

\subsubsection{Die Grondwet en gelykheid}

Dit was 'n onbetwiste feit in hierdie saak dat die bepalings van artikel 9(4) van die Grondwet, 1996, horisontaal toegepas moet word (Du Toit, 2001:241) en selfs die bewoording van hierdie artikel wat bepaal dat 'geen persoon' onbillik teen 'iemand' mag diskrimineer nie as 'n interne reguleringmeganisme van hierdie horisontale aanwending geïnterpreteer moet word. Alhoewel die regter die belang van artikel 9 as ' $n$ fundamentele waarde van die Grondwet, 1996, erken het, het hy besluit om die aangeleentheid eerder ingevolge die gemenereg te beslis en dit nie op 'n direkte toepassing van hierdie grondwetlike waarborg te grond nie.

\subsubsection{Ratio decidendi van beslissings en kommentaar hierop}

Dit was die eerste hofsaak van hierdie aard wat in ' $n$ post-konstitusionele Suid-Afrika plaasgevind het. Die regter het hom goed van sy taak gekwyt om al die relevante punte te bespreek. Daar was egter'n paar uitlatings wat problematies was, maar nie werklik van toepassing is op die artikel nie, deurdat die regter foutiewelik na ' $n$ trust as ' $n$ regspersoon verwys het en ook ' $n$ testament aan ' $n$ kontrak gelykgestel het.

In die saak bespreek Regter Griesel die beginsel van onbillike diskriminasie in detail en hy beroep hom op die drie kriteria wat deur die Konstitusionele hof neergelê is in die saak van Harksen v Lane NO and Others ([1998] (1) SA 300 (KH) par 53) om te bepaal of diskriminasie billik of onbillik is (Syfrets-saak [2006] (10) BCLR 1214 (K) par 33). Regter Griesel pas egter nie hierdie toets volledig toe nie. Hy bevind wel dat die gronde waarop in hierdie saak gediskrimineer word, naamlik ras, geslag en geloof wel deel vorm van die gelyste gronde en daarom kan daar aangeneem word dat hierdie diskriminasie onbillik is. Maar, op grond van die Harksen toets moes die Regter egter verder gegaan het en die effek van artikel 36 van die Grondwet, 1996, alombekend as die 'beperkingsklousule,' in ag geneem het om te bepaal of die diskriminasie wat veroorsaak word deur die toepassing van die testateur se testeervryheid 'n regverdigbare beperking is of nie.

Regter Griesel het egter aangevoer dat hy hierdie saak gaan beslis op die gemeenregtelike verbod op testamentêre bepalings wat nie teen openbare belang kan wees nie en nie deur 'n direkte toepassing van die grondwetlike bepalings nie, wat dus bogenoemde versuim om die toets vir onbillike diskriminasie verder uit te brei, nie ' $n$ wesenlike probleem gemaak het nie. 
Indien die uitspraak egter noukeurig deurgegaan word, is dit duidelik dat daar bitter min verwysing na die gemeenregtelike kernbronne is en word daar baie meer klem gelê op grondwetlike toepassing (Van der Westhuizen \& Slabbert, 2007:212). Van belang hier is dat die Regter die reg tot testeervryheid erken en respekteer, maar dat hierdie reg nie absoluut is nie (Wood-Bodley, 2007). Die oorkoepelende effek van die Grondwet, 1996, is hier beklemtoon en die duidelike aversie van enige mate van diskriminasie is weereens bevestig.

\subsection{University of KwaZulu-Natal v Makgoba and Others (17124/2005) [2009] ZAKZDHC 28 (17 JULIE 2009)}

en die appèlsaak in hierdie aangeleentheid:

Curators, Emma Smith Educational Fund v University of KwaZulu-Natal 2010 (6) SA 518 (HHA)

\subsubsection{Agtergrond}

Sir Charles George Smith het in 1938 by wyse van sy testament 'n derde van die restant van sy boedel aan die Raad van die Natalse Universiteitskollege bemaak om in trust te hou, naamlik die Emma Smith Educational Fund en om die inkomste aan te wend vir die onderhoud en tersiêre onderrig van arm Europese meisies 'born of British South African or Dutch South African parents' woonagtig te Durban.

Die applikant het die hof genader vir'n bevel om, ingevolge artikel 13 van die Wet op die Beheer oor Trustgoed, 57 van 1988, die trustdokument te wysig deur die skrapping van die woorde 'European', 'British' en 'Dutch South African' en die vervanging van die woord 'Durban' met die woorde 'Ethekwini Municipality' (vir doeleindes van hierdie artikel is die punt nie relevant nie en gaan die hof se bevindinge ten opsigte van hierdie punt nie bespreek word nie).

Die hof van eerste instansie het die applikant se bedes toegestaan op grond van artikel 13 van die Wet op die Beheer oor Trustgoed, en alhoewel die kurator teen die uitspraak geappelleer het en in die appèlaansoek alternatiewe wysigings voorgestel het, is die appèl van die hand gewys.

\subsubsection{Openbare beleid en staatsinstellings}

Die hof van eerste instansie het sy beslissing grootliks op die uitspraak in Minister of Education \& another $v$ Syfrets Trust Ltd NO \& another ([2006] (4) SA 205 (K)) gebaseer. Die feit dat die bepalings teen die beginsel van openbare belang was, gepaardgaande met die feit dat die Universiteit, wat die bemaking moes administreer, 'n staatsinstelling was, wat beklee was met al die verpligtinge verbonde aan 'n staatsinstelling, was grootliks die motivering vir die hof a quo se toestaan van die bevel tot die wysiging van die trustakte.

Die bevinding is bevestig in die appèlhof. Daar is 'n groter verantwoordelikheid op staatsinstellings om die beginsels van die Grondwet te bevorder en om te verseker dat onregverdige diskriminasie uitgeroei word. Die Universiteit sal nie bemakings kan administreer wat as onregverdige diskriminasie geklassifiseer word nie.

\subsubsection{Testeervryheid en die balans tussen die grondwetlik gewaarborgde regte}

Die kurators het in hierdie saak hul daarop beroep dat die wysiging van trustbepalings ' $n$ inbreuk sal maak op 'n individu se testeervryheid. Die hof het egter beslis dat daar wel beperkings op testeervryheid geplaas kan word, veral in gevalle waar dit van toepassing is op staatsinstellings 
wat beurse moet administreer vir opvoedkundige doeleindes waarin daar onregverdig en teen die beginsel van openbare belang gediskrimineer word.

\subsubsection{Gelykheid, openbare beleid en onbillike diskriminasie}

Die hof het bevind dat die beginsel van gelykheid 'n grondwetlike reg is, soos vervat in artikel 9 van die Grondwet, 1996. In artikel 9(4) van die Grondwet, 1996, word daar bepaal dat nasionale wetgewing geïmplementeer moet word om onbillike diskriminasie te voorkom of te belet. Die wetgewing wat spesifiek hier van toepassing is, is die Wet op die Bevordering van Gelykheid en die Voorkoming van Onbillike Diskriminasie, 4 van 2000. Die hof het verwys na die bepalings vervat in die aanhef, artikel 7 en die bylae van hierdie wet om duidelik te illustreer dat die bepalings in hierdie trustakte teen die beginsel van gelykheid is en dat hierdie wetgewing definitief van toepassing is ten opsigte van testamentêre liefdadigheidstrusts. Dit word hier duidelik gestel dat geen diskriminasie op grond van ras toegelaat sal word nie en die wet verbied dit ook om enige beurse aan leerders van voorheen benadeelde groepe te weerhou.

Bertelsmann AJA verwys ook as gesag ten opsigte van hierdie punt na Honoré (Cameron et al., 2002:171-172):

'...the objects of a trust will have to conform with the disavowal of unfair discrimination under the 1996 Constitution and the promotion of Equality and Prevention of Unfair Discrimination Act, which envisage equality even in person-to-person relations.'

\subsubsection{Ratio decidendi van beslissings en kommentaar hierop}

Die Appèlhof het beslis dat artikel 13(a) en (c) van die Wet op die Beheer oor Trustgoed wel van toepassing is en dat die hof korrek was om 'n wysiging van die bepalings in hierdie trustakte op grond van hierdie artikels te gelas. Die bepalings dat die beperkings wat deur die uitsluiting van 'n spesifieke ras op die oorspronklike doel van die testateur se bemaking geplaas word, asook die feit dat hierdie bepaling teen die beginsel van openbare belang is plaas, dit binne die kader van artikel 13 (57 van 1988).

Die regter het in hierdie saak baie staatgemaak op die uitspraak van Regter Griesel in die saak van die Minister of Education \& another v Syfrets Trust Ltd No \& another ([2006] (4) SA 205 (K)) en dus die benadering wat in die Syfrets-saak gevolg is in die Appèlhof bevestig.

In hierdie saak word die belangrikheid van die uitwissing van enige vorm van diskriminasie op grond van ras duidelik gemaak en bevestig, maar wat interessant is, is dat die diskriminerende bepaling op grond van geslag glad nie deur die appellant of respondent behandel is nie, waar diskriminasie op grond van geslag, wel een van die gronde van wysiging in die Syfrets-saak was. Die kurator het in hierdie saak slegs kortliks verwys na die feit dat vroue as klas steeds benadeel word, maar die regter het nie op hierdie stelling uitgebrei of dit bespreek nie en al afleiding wat gemaak kan word, is dat al die partye betrokke die reservering van hierdie beurs aan slegs dames as billike diskriminasie geag het. 


\subsection{In re Heydenrych Testamentary Trust and Others 2012 (4) SA 103 (WKH)}

\subsubsection{Agtergrond}

Die administrateur van drie liefdadigheidstrusts het versoek dat die hof ingevolge artikel 13 van die Wet op die Beheer oor Trustgoed, 57 van 1988, die diskriminerende beperkings in die onderskeie trustaktes wysig.

- Die Heydenrych Trust

Benjamin Gotlieb Heydenrych het op 19 Junie 1943 'n testament opgestel. Die testament bepaal dat die restant van sy boedel in 'n trust gehou moet word tot na sy vrou se dood en dat tweederdes van die restant daarna belê moet word vir die onderrig van Europese seuns van Protestantse geloof en dat ten minste die helfte van die seuns van Britse afkoms moet wees.

Die hof het beslis dat die term 'Europese seuns' geskrap moet word en vervang word met die woord "persone" en dat die klousule wat bepaal dat ten minste die helfte van die seuns van Britse afkoms moet wees ook geskrap moet word.

\section{- Die Houghton Trust}

Op 9 Mei 1989 het Dorothy Helen Houghton 'n testament opgestel waarin voorsiening gemaak is vir die oprigting van die Cyril Houghton Beurstrust na haar dood. Die netto inkomste van die trust moet aangewend word om beurse beskikbaar te stel vir die opvoeding van twee of meer SuidAfrikaanse blanke seuns. Die hof het beslis dat enige verwysing na die term blanke geskrap moet word en dat alle verwysings na die manlike geslag gelees en vertolk moet word om die vroulike geslag ook in te sluit.

- Die George King Trust

George King het 'n testament op 13 Januarie 1987 verly. Ingevolge die testament het hy voorsiening gemaak vir die oprigting van die Trust wat die George King Beurs moes administreer. Hierdie beurs moes deur die Universiteit van Kaapstad geadministreer word en die doel van hierdie beurs was om finansiële bystand te verleen aan belowende musiekstudente van goeie karakter in behoeftige omstandighede en was beperk tot blanke studente van die Protestantse geloof. Die hof het hier ook gelas dat enige verwysing na die term 'blanke' geskrap moet word.

\subsubsection{Gelykheid, openbare beleid en onbillike diskriminasie}

Regter Goliath het in sy beslissing verwys na die bepalings van artikel 9 van die Grondwet, 1996, die bepalings van artikel 4 en artikel 29 van die Wet op die Bevordering van Gelykheid en die Voorkoming van Onbillike Diskriminasie, 4 van 2000 en dit toegepas om te bepaal dat die betrokke klousules in die testamente neerkom op onbillike en onregverdige diskriminasie wat teen die beginsel van openbare beleid is. Dit is weereens bevestig dat diskriminasie op grond van ras nie geduld sal word nie.

Die testamentêre bepalings in die saak van $R E$ Heydenrych Testamentary Trust and Others ([2012](4) SA 103 (WKK) dat die beurse slegs van toepassing was op manlike persone is ook as onbillike diskriminasie beskou alhoewel die redes vir die uitsluiting van vrouens ten tyde van die verlyding van die testament nie as seksisties geïnterpreteer is nie. Dit was nie moontlik om die onderskeie bedoelings van die betrokke partye in die opstel van die testamente te bepaal nie. 
Die hof het bevestig dat die bedoeling om te diskrimineer nie 'n voorvereiste vir onbillike diskriminasie is nie (par 13).

\subsubsection{Wetgewing}

Die regter het hom in sy beslissing beroep op die bepalings van artikel 13 van die Wet op die Beheer oor Trustgoed wat bepaal dat ' $n$ trust gewysig kan word, eerstens, indien die bepaling gevolge het wat die oprigter nie kon voorsien nie en tweedens, indien die bepaling nie meer uitvoerbaar is nie of die belange van die begunstigdes negatief sal beïnvloed of teen die beginsel van openbare belang is.

Op grond van bewyse wat aan die hof voorgelê is, was dit duidelik dat die testateurs van die onderskeie testamente nie die veranderende omstandighede kon voorsien het nie. Die testamente is almal voor die implementering van die nuwe Grondwet opgestel en verly. Die testateurs sou dus nie kon voorsien hoe die toekenning van beurse vir slegs seuns of vir persone van Europese of Britse afkoms in die toekoms as onbillike diskriminasie geklassifiseer kon word en as ongrondwetlik beskou sou word nie.

Dit sou nie vir die testateurs en testatrise moontlik gewees het om te voorsien dat die uiteindelike effek van hierdie ongrondwetlike bepalings sou wees dat die oorspronklike doel van die trust belemmer sou word deur die feit dat die administrateurs nie meer die beurse wil administreer op grond van die diskriminerende bepalings wat teen die beginsel van openbare belang geag sou word nie. Die hof het dus gelas dat daar voldoende bewyse is en die wysiging toegestaan is op grond van die bevoegdhede wat deur artikel 13 van die Wet op die Beheer oor Trustgoed, 57 van 1988, aan hom verleen word.

\subsubsection{Ratio decidendi van beslissings en kommentaar hierop}

Hierdie saak is ook beslis op grond van artikel 13 van die Wet op die Beheer oor Trustgoed, 57 van 1988. Daar is bevind dat hierdie spesifieke bepalings wat gewysig moes word gevolge meegebring het wat die oprigter nie kon voorsien nie en dat die betrokke bepaling teen die beginsel van openbare belang is.

Daar was wel een opvallende punt wat uitgelig moet word en dit was die versuim van die applikante om te versoek dat die woord 'Protestantse geloof' in die trustakte geskrap word. Dit is tog ook 'n vorm van diskriminasie soos omskryf in artikel 9(3) van die Grondwet, 1996, en in die Syfrets-saak ([2006] (10) BCLR 1214) is die bepalings wat verwys het na 'Jewish Descent' (par 4) geskrap. Die regter het ook versuim om in sy uitspraak enige iets oor hierdie weglating te noem.

My redenasie is dat die rede vir hierdie versuim gevind kan word in die uitspraak van die Syfretssaak waar daar 'n verbod geplaas is op persone om voordeel te ontvang ingevolge hierdie beurs indien hulle van Joodse afkoms is (par 34). Die diskriminasie sal onbillik wees indien ' $n$ spesifieke geloof van enige voordeel uitgesluit word. In hierdie geval egter word 'n spesifieke godsdienstige groep slegs bevoordeel deurdat die bepaling lees dat individue wat voordeel wil ontvang van die Protestantse geloof moet wees (Van Wyk, 2005:39). Alhoewel ek nie heeltemal saamstem met die interpretasie van hierdie bepaling nie, is dit hoe dit op hierdie stadium deur die howe geïnterpreteer en toegepas word. 


\subsection{EX PARTE BOE TRUST LTD 2009 (6) SA 470 (WKK) en IN RE BOE TRUST LTD AND OTHERS NNO 2013 (3) SA 236 (HHA)}

\subsubsection{Agtergrond}

In dié saak het die testatrise op 14 Julie 2002 'n testament opgestel. Sy het in haar testament 'n beurs gestig tot voordeel van wit Suid-Afrikaanse studente wat'n MSc-graad in organiese chemie aan sekere universiteite in Suid-Afrika behaal het en wat van plan was om hul studie met ' $n$ doktorsgraad aan ' $n$ "universiteit in Europa of in Brittanje" te voltooi. Een van die vereistes vir die toekenning van die beurs was egter dat hierdie studente na die voltooiing van hul studie vir 'n bepaalde tydperk na Suid-Afrika moet terugkeer.

Daar was ook 'n bepaling in die testament dat indien die trustees nie in staat is om uitvoering te gee aan hierdie beursbemaking nie, die inkomste van die trust jaarliks, in gelyke dele, aan 10 gespesifiseerde liefdadigheidsorganisasies bemaak moet word.

Die testatrise was bewus daarvan dat die oorspronklike bepaling moontlik as diskriminerend geag kan word en daar dan nie uitvoering daaraan gegee sou word nie, maar ongeag hierdie kennis het die testatrise steeds nie haar testament gewysig nie.

Die trustees van die trust het die registrateurs van die betrokke universiteite gekontak om te bepaal of hulle die beursbemaking, onderhewig aan die beperkings uiteengesit in die testament, sou aanvaar. Die universiteite het aangetoon dat hulle die beursbemaking slegs sal aanvaar indien dit vir alle rasse beskikbaar is.

Die trustees het die Hooggeregshof genader vir 'n bevel om die woord "wit" uit die betrokke klousule van die trustakte te skrap omdat dit direk of indirek diskrimineer teen potensiële begunstigdes van die beurse op grond van ras. Die regter het gelas dat, in hierdie geval, die uitdruklike wense van die testatrise gerespekteer moet word en indien die universiteite weier om die beurs onder die bestaande voorwaardes te bestuur, die bemaking onmoontlik is en dus nie uitvoerbaar nie en dat die trustinkomste gelas word om aan die 10 gespesifiseerde liefdadigheidsorganisasies te gaan.

Nadat die howe beslis het oor die saak Curators, Emma Smith Educational Fund v University of KwaZulu-Natal and Others ([2010] (6) SA 518 (HHA)) het die trustees van die BOE-Trust gevoel 'n nuwe juristiese presedent is geskep en het hulle teen die uitspraak van Mitchell AJ geappelleer. Die appèl is egter afgewys.

\subsubsection{Testeervryheid}

Die hof het weereens hier verwys na die feit dat die reg op testeervryheid deur artikel 25 van die Grondwet, 1996, gewaarborg word en ook na die erkenning wat aan hierdie waarborg verleen is in die Syfrets-saak ([2006] (10) BCLR 1214 (K)). Die belang van testeervryheid is dus 'n begrip wat steeds wel deur ons howe gerespekteer word.

Testeervryheid is egter nie absoluut nie en die balans wat tussen testeervryheid en die beperkings op hierdie beginsel gevind moet word, is deur Innes ACJ soos volg verwoord:

Now the golden rule for the interpretation of testaments is to ascertain the wishes of the testator from the language used. And when these wishes are ascertained, the court is bound to give effect to them, unless we are prevented by some rule of law from doing so (Robertson v Robertson's Executors [1914] $A D 503$ by 507). 
Dit is dus belangrik om te bepaal wat die bedoeling van die testatrise was toe sy 'n addisionele klousule ingevoeg het wat van toepassing sou wees indien dit onmoontlik was om aan die oorspronklike bepaling uitvoering te gee. Sy was bewus van die feit dat die bemaking dalk nie sou kon slaag op grond van die bepaling dat dit slegs aan blanke studente moet gaan nie. Sy het dus hierdie onmoontlikheid hanteer deur 'n alternatiewe bemaking in te sit. Dus, indien die oorspronklike bemaking nie kan slaag nie, om watter rede ook al, moet die fondse aan die 10 liefdadigheidsinstansies bemaak word.

\subsubsection{Staatsinstellings}

In hierdie geval kan die oorspronklike bemaking nie slaag as gevolg van die groter verantwoordelikheid wat op die verskillende universiteite, as staatsinstellings, rus nie om nie by enige diskriminerende optrede betrokke te raak nie. Dit is as gevolg van die weiering van die universiteite om die beurse te administreer dat daar nie aan die oorspronklike diskriminerende bemaking uitvoering gegee kan word nie, en dienooreenkomstig is die bemaking onmoontlik en moet geskrap word ingevolge artikel 13 van die Wet op die Beheer oor Trustgoed. Die alternatiewe bemaking - waar die fondse aan die 10 spesifieke liefdadigheidsinstansies gaan - sal dan geïmplementeer moet word.

\subsubsection{Gelykheid, openbare beleid en onbillike diskriminasie}

In die Appèlhof is dit beklemtoon dat die beginsel van openbare belang beslis erken moet word.

Eerstens, deur te verwys na die uitspraak van die Syfrets-saak ([2006] (4) SA 205 (K)) waarin daar bepaal is dat testeervryheid wel beperk word indien dit teen openbare belang is en tweedens, dat die gemenereg ook bepaal dat ' $n$ testamentêre bemaking ongeldig is indien dit teen openbare belang is. Die hof het verder aangevoer dat openbare belang nie 'n statiese konsep is nie. Sekere bepalings wat in die verlede in teenstelling met die beginsel van openbare belang was, kan vandag as aanvaarbaar gesien word en vice versa.

Die regter het egter verklaar dat in hierdie geval die betrokke bepaling nie duidelik in teenstelling met openbare belang is nie. Ingevolge artikel 9(3) van die Grondwet, 1996, word diskriminasie wat onregmatig is, verbied en dat diskriminasie wat ontwerp is om 'n wettige doel te bereik nie onregverdig is nie, byvoorbeeld indien hierdie diskriminasie aangewend word om onregte wat in die verlede aangerig is op grond van ras en geslag te hanteer. Dus sal 'n handeling slegs teen openbare belang geag word as dit beslis word dat die handeling onregverdige diskriminasie teweegbring. Hy het hierdie argument gesteun deur te verwys na die bestaande situasie waar blanke Suid-Afrikaners emigreer nadat hulle hul studie in Suid-Afrika voltooi het en dat dit die land van noodsaaklike kennis en vaardighede beroof. Daar is aangevoer dat die testatrise, deur middel van hierdie beurs, wou verseker dat Suid-Afrika in 'n mate kundiges behou deurdat die beurshouers na hulle studie na Suid-Afrika moet terugkeer.

Die hof het egter nie verder oor hierdie standpunt uitgebrei en 'n spesifieke beslissing hieroor gemaak nie.

\subsubsection{Wetgewing}

Artikel 13 van die Wet op die Beheer oor Trustgoed, 57 van 1988, verleen wye bevoegdhede aan die howe met betrekking tot die wysiging van trusts en is ' $n$ verdere uitbreiding van die gemeenregtelike uitsonderings op die voluntas testatoris servande est beginsel: 
'Indien 'n trustdokument ' $\backslash$ 'n bepaling bevat wat gevolge teweegbring wat die oprigter van

'n trust na die hof se oordeel nie beoog of voorsien het nie en wat -

(a) die bereiking van die oprigter se oogmerke belemmer; of

(b) die belange van bevoordeeldes benadeel; of

(c) in stryd met die openbare belang is,

kan die hof op aansoek van die trustee of enige persoon wat na die hof se oordeel voldoende belang by die trustgoed het, enige sodanige bepaling skrap of wysig of ten opsigte daarvan enige bevel gee wat daardie hof billik ag, met inbegrip van ' $n$ bevel waarby bepaalde trustgoed deur bepaalde ander goed vervang word, of 'n bevel wat die trust beëindig.'

Vir die hof om 'n wysiging van 'n bepaling in 'n trustakte te gelas, ingevolge hierdie artikel, kan daar nie slegs aangevoer word dat die bepaling teen openbare beleid is nie, dit is ook nodig dat die hof moet beslis dat die spesifieke bepaling omstandighede teweeggebring het wat die testateur nie sou kon voorsien het nie. Indien daar nie aan hierdie vereistes voldoen nie, is die howe slegs by magte om bepalings wat teen openbare beleid is gedeeltelik of in die geheel te skrap (par 20).

Dit is ook maklik, in gevalle soos die Syfrets-saak ([2006] (10) BCLR 1214 (K)) om aan te voer dat daar ' $n$ verandering van die samelewing se siening van openbare beleid tussen die opstel van die testament en die implementering van die testament was, wat die testateur nie sou kon voorsien het nie en wat die spesifieke testamentêre bepaling nou teen die beginsels van die huidige openbare beleid is.

In hierdie saak is dit egter nie die geval nie. Die testament is in 2002 verly en daar is gelas dat die testateur bewus was van die feit dat hierdie bemaking as ongeldig gesien kan word en steeds voortgegaan het met die bemaking. Die feit wat die spesifieke bepaling onuitvoerbaar maak, is dus nie dat die testateur nie die veranderende omstandighede voorsien het nie, maar die weiering van die betrokke universiteite om die beurs te aanvaar en te administreer op grond van die persepsie dat die bepaling teen die beginsel van openbare beleid is.

Die testatrise het hierdie moontlikheid voorsien en het 'n alternatiewe bemaking daargestel.

Die applikant het versoek dat daar aan die oorspronklike doel van die bemaking uitvoering gegee moet word deur die spesifieke bemaking te wysig sodat dit nie meer teen openbare beleid sal wees nie.

Die hof het egter aangevoer dat daar nie in hierdie geval aan die gronde voldoen word om die trustakte te wysig, soos uiteengesit in die Wet op die Beheer oor Trustgoed (Art 13 van Wet 57 van 1988) nie en dat die howe nie die testatrise se testeervryheid gaan inperk om testamente te herskryf om die trustees en begunstigdes te pas nie (par 13). Die hof het dus in hierdie geval gelas dat geen wysiging ingevolge hierdie trustakte gemaak gaan word nie.

\subsubsection{Ratio decidendi van beslissings en kommentaar hierop}

Hierdie hofsaak het baie bespreking onder juriste laat ontstaan. Hierdie saak was uniek in dié opsig dat die betrokke testament 'n alternatiewe klousule bevat het. Uit getuienis was dit duidelik dat die testatrise bewus was van die feit dat haar bemaking moontlik onuitvoerbaar kan wees en sy het toe voorsiening gemaak vir 'n alternatiewe bemaking (Ex Parte BOE Trust Ltd [2009] (6) SA $470(W K K))$. 
Hierdie saak moet nie geïnterpreteer word dat die howe versuim het om 'n klousule in 'n testament wat op grond van ras diskrimineer, te skrap nie. Die hof het slegs bepaal dat, aangesien die testament wel ' $n$ klousule bevat het waarin daar voorsiening gemaak word vir ' $n$ alternatiewe bemaking indien daar nie uitvoering gegee kan word aan die diskriminerende bemaking nie, hierdie alternatiewe klousule toegepas moet word en dat dit nie nodig is om die testament te wysig nie. Die "onmoontlike klousule", met sy beperkende rasbepaling, sou dus net geïgnoreer word en die alternatiewe klousule sou geïmplementeer word.

Dit was hierdie alternatiewe klousule wat die effek gehad het dat artikel 13 van die Wet op die Beheer oor Trustgoed, 57 van 1988 nie van toepassing kon wees nie. Die testatrise het voorsien dat die oorspronklike bepaling onuitvoerbaar kon wees en die saak het die erkenning en implementering van 'n testateur of testatrise se bedoeling judisieel onderskryf.

Die regter het hier korrek beslis dat die aansoek om die klousule te skrap, moet misluk en dat die alternatiewe klousule geïmplementeer moet word.

Die blyk uit ook uit hierdie beslissings dat die regslui se siening oor die implementering van klousules wat ingevolge ras diskrimineer besig was om te verslap en dat, in hierdie saak, daar dalk 'n moontlikheid was dat die regter nie hierdie klousule sou skrap indien die universiteite wel bereid was om die beurs te administreer nie (EX Parte BOE Trust Ltd No \& others [2010] JOL 26193 (WKK) by par 13-16).

I am not satisfied that the provisions concerned are as clearly contrary to public policy as the trustees believe. Section 9(3) of the Constitution proscribes discrimination which is unfair. It is recognised that discrimination designed to achieve a legitimate objective is not unfair. Such legitimate objectives are, for example, the need to redress past injustices based on gender and race.

During the post-constitutional years much has been said and written about the increasing trend amongst white graduates of our universities to emigrate upon completion of their education, thereby depriving the country of benefit of their skills obtained...

\section{GEVOLGTREKKING}

Uit die ontleding van bostaande hofsake is dit duidelik dat die Suid-Afrikaanse howe se benadering tot die interpretasie van al die konstitusionele, gemeenregtelike en privaatregtelike elemente, op dieselfde neerkom al verskil die ratio in sommige toepassings geweldig.

In al die gevalle het die howe die horisontale aanwending van die normatiewe waardes van die Grondwet, 1996, in die gemenereg erken en bevestig (NK v Minister of Safety and Security, 2005: par 17). Die beginsel van gelykheid, openbare beleid, billike diskriminasie en onregverdige diskriminasie is aan die hand van die bepalings van die Grondwet geïnterpreteer. Die feit dat openbare belang nie staties is nie en dat die regters 'n sekere mate van interpretasiebevoegdheid by hierdie konsep het, is ook uitgelig (Du Toit 2007:107). Wat egter duidelik blyk is dat daar geen eenvormige gronde is wat die howe tans toepas om beslissings te maak aangaande die wysigings van diskriminerende bepalings in testamentêre trusts nie.

My betoog is dat die Suid-Afrikaanse howe se hantering van diskriminerende testamentêre bepalings nie konsekwent is nie. 


\subsection{Testeervryheid}

In al die hofsake is dit duidelik gestel dat testeervryheid steeds gesien moet word as een van die hoekstene van die Suid-Afrikaanse erfreg. Die reg wat aan individue verleen word om by hul dood oor hul bates te beskik, word gerespekteer en beskerm. Die indirekte grondwetlike waarborg tot individuele testeervryheid was egter nooit 'n konsep wat absolute testeervryheid in ons reg erken nie, en testeervryheid was altyd onderhewig gewees aan sekere gemeenregtelike en statutêre beperkings. Een van hierdie beperkings is dat 'n bemaking nie teen die beginsel van openbare belang mag indruis nie (Corbet et al., 2001:107). Daar is ook duidelik beklemtoon dat daar 'n balans gehandhaaf moet word tussen die reg op testeervryheid en die reg op gelykheid en vryheid van diskriminasie, soos wat in die Grondwet gewaarborg word.

\subsection{Staatsinstellings}

Dit is egter belangrik om te beklemtoon dat daar nog nie in die Suid-Afrikaanse reg 'n beslissing was waar daar aansoek gedoen is om wysiging op grond van diskriminasie in ' $n$ 'private' testamentêre trust nie (De Waal, 2012:par 3G12).

In al die betrokke sake was daar 'n mate van 'state action' deurdat dit universiteite was wat die beurse moes administreer, en soos hierbo verduidelik, berus daar 'n groter verantwoordelikheid op staatsinstellings om te verseker dat hulle hulself in geen opsig aan diskriminerende praktyke skuldig maak nie. Dit sal interessant wees om te sien of die howe ook wysigings van private testamentêre trusts so vinnig sal goedkeur.

\subsection{Gelykheid, openbare beleid en onbillike diskriminasie}

Diskriminerende bepalings word op meriete beoordeel en nie net voor die voet nie. In die Syfretssaak ([2006] (10) BCLR 1214 (K)) word die bepalings wat individue verbied om 'n voordeel te ontvang op grond van ras, geslag en geloof geskrap, maar slegs omdat hierdie bepalings voorheen benadeelde groepe uitsluit en verbied om die spesifieke voordeel te ontvang. In die Heydenrechsaak ([2012] (4) SA 103) word 'n bepaling wat die inkomste reserveer vir individue van 'n spesifieke geloof nie geskrap nie, moontlik op grond van die feit dat 'n spesifieke groep bevoordeel word en nie geteiken word nie.

So ook word bepalings gewysig wat beurse reserveer vir manlike studente, maar waar beurse gereserveer word vir vroulike studente word dit weereens nie gewysig nie - vroue word geag deel van voorheen benadeelde groepe te wees (Curators, Emma Smith Educational Fund v University of KwaZulu-Natal [2010] (6) SA 518 (HHA). Dit is alom aanvaarbaar dat diskriminasie onbillik moet wees om 'n skrapping of wysiging te regverdig.

\subsection{Grondwet}

In al die genoemde beslissings is artikel 9 van die Grondwet van die Republiek van Suid-Afrika, 1996, bespreek en die belang as oorkoepelende gesag bevestig, maar in nie een van die beslissings het die regters 'n direkte toepassing van die grondwetlike beginsels gebruik om hul beslissings te staaf nie. So ' $n$ interpretasie sal interessant wees en dalk net wat nodig is om as basis te gebruik om 'n geskikte stelreël te ontwikkel. 


\subsection{Ratio decidendivan beslissings}

Die gronde waarop die howe hul beslissings baseer het, was:

- Artikel 13 van die Wet op die Beheer oor Trustgoed (57 van 1988).

- Die gemenereg wat enige testamentêre bemakings verbied wat onwettig, immoreel en teen openbare belang is.

Dit was ook duidelik uit die hofsake dat die howe se benadering van die interpretasie van artikel 13 van die Wet op die Beheer oor Trustgoed en ook die gemeenregtelike beginsels nie konsekwent was nie, maar dat ongeag hierdie verskillende benaderings, dieselfde resultaat verkry word. Die hantering van bemakings wat teen die beginsel van openbare belang is, sal geskrap of gewysig word, veral bemakings wat bepalings bevat waar daar onderskei word op grond van ras (Pace \& Van der Westhuizen, 2014). Hierdie tendens is in elke hofsaak bevestig en het parallel geloop met die ontwikkeling van die nuwe demokrasie en die sosio-ekonomiese en sosiale omstandighede in Suid-Afrika.

\section{SLOT}

Alhoewel dit duidelik is dat die howe nie altyd al die beginsels in sake van hierdie aard eenvormig toepas nie, is die gevolge egter duidelik. Diskriminerende bepalings in testamentêre liefdadigheidstrusts wat deur staatsinstellings geadministreer word, sal nie staande bly nie en daar is geen twyfel dat die howe hul reg op wysiging sal toepas om sulke bepalings te skrap nie.

Om die negatiewe effekte van hofsake, skrappings en wysigings van trustbepalings te bekamp, sal die beste advies wees om persone oor die gevare te adviseer en dan, soos gesien in die $B O E$-saak ([2009] (6) SA 470 (WKK)), 'n alternatiewe bemaking uiteen te sit, net vir ingeval die oorspronklike "diskriminerende bepalings" nie uitvoerbaar is nie.

Die politieke en sosio-ekonomiese toestande in Suid-Afrika is steeds nie van so 'n aard dat openbare belang enige tipe diskriminasie (veral op grond van ras) sal toelaat nie. Dit sal egter help indien daar 'n stelreël ontwikkel kan word wat duidelik uiteensit wanneer diskriminerende bepalings as onbillik of billik geïnterpreteer kan word, wat meer spesifiek is as die algemene bepalings uiteengesit in die Harksen-saak ([1998] (1) SA 300 (KH)).

In die lig van die veranderende aard van die beginsel van openbare belang, sal dit moeilik wees om so 'n spesifieke stelreël uiteen te sit en sal basiese beginsels eerder vasgestel moet word. Dit blyk egter dat die huidige siening van openbare belang wel stadig aan die ontwikkel is, in so'n mate dat sekere diskriminerende bepalings baie strenger geïnterpreteer word as ander. Dit is noodsaaklik dat die howe hul magte gebruik om ontwikkeling van ons trustreg sowel as die gemenereg te bewerkstellig om sodoende 'n werkbare oplossing te vind - 'n tipe grondwetlike gebaseerde boni mores kriteria soos wat deur Francois du Toit bepleit word (De Waal, 2005).

Dit sal wys wees om, in die interim, versigtig te wees om diskriminerende bepalings in liefdadigheidstrusts waar openbare instansies betrokke is, in te skryf. Die Suid-Afrikaanse politieke landskap en die interpretasie van die beginsel van openbare belang is nog nie van so 'n aard dat dit as aanvaarbaar geag sal word nie en dit sal wys wees om eerder in hierdie geval 'n konserwatiewe benadering te volg en sodoende te verseker dat jou testeervryheid nie beperk word nie en daar voldoende gehoor aan jou wense gegee word (Wood-Bodley, 2007: 687-702). 


\section{VeRWYSINGSLYS}

BOE Trust Ex Parte Ltd 2009 (6) SA 470 (WKK) en

In Re BOE Trust Ltd and Others NNO 2013 (3) SA 236 (HHA)

${ }^{1}$ Convention on the Elimination of All Forms of Discrimination against Women - 1979.

Corbett, M.M. et al. (2001). The Law of Succession in South Africa, $2^{\text {nd }}$ edition. Claremont: Juta.

Curators, EMMA Smith Educational Fund v University of KwaZulu-Natal 2010 (6) SA 518 (HHA).

Currie, I. \& De Waal, J. (2013). The Law of Succession in South Africa, $6^{\text {nd }}$ edition. Cape Town: Juta.

De Waal, M.J. (2012). The Law of Succession and the Bill of Rights. SI30. Butterworths.

Du Toit, F. (2001). The Constitutionally Bound Dead Hand? The Impact of Constitutional Rights and Principles on Freedom of Testation in South Africa. Stellenbosch Law Review 222 - 257.

Du Toit, F. (2005). An evaluation of the limitation imposed upon freedom of testation by section 13 of the Trust Property Control Act 57 van 1988. Journal for Juridical Science, 30(1), 39-51.

Du Toit, F. (2007). South African Trust Law: Principles and Practice, $2^{\text {nd }}$ edition. Durban: Lexis Nexis.

Du Toit, F. (2012). Constitutionalism, Public Policy and Discriminatory Testamentary Bequests - A Good Fit Between Common Law and Civil Law in South Africa's Mixed Jurisdiction?. Tulare European and Civil Law Forum Vol 27, 97-165.

Grondwet van die Republiek van Suid Afrika, 108/1996.

Harksen $v$ Lane NO and Others 1998 (1) SA 300 (CC) by par 53

In Re Heydenrych Testamentary Trust and Others 2012 (4) SA 103 (WKK)

Honorè, A.M. \& Cameron, E. et al. (2002). Honorè's South African law of trusts, $5^{\text {th }}$ edition. Lansdowne: Juta Law.

Kruger, M. (2011). The role of public policy in the law of contract, revisited. South African Law Journal, 128(4), 712-740.

Minister of Education and Another v Syfrets Trust Ltd NO and Another 2006 (4) SA 205 (.)

NK v Minister of Safety and Security 2005 (6) SA 419 (CC) by par 17.

Pace, R.P. \&Van der Westhuizen, W.M. (2013). Wills and Trusts. SI 13. Durban: Butterworths.

Robertson v Robertson's Executors 1914 AD 503 by 507

University of KwaZulu-Natal v Makgoba and Others (17124/2005) [2009] ZAKZDHC 28 (17 JULIE 2009)

Van der Westhuizen, C. \& Slabbert, M. (2007). Wysigings van die bepalings van ' $n$ liefdadigheidstrust. Tydskrif vir die Suid-Afrikaanse Reg, 206-214.

Van Wyk, M. (2005). Die Grondwetlikheid van Geloofsklousules in Testamente. Ongepubliseerde LLMskripsie. Noordwes-Universiteit.

Wet op die Beheer oor Trustgoed 57/1988.

Wet op die Bevordering van Gelykheid en die Voorkoming van Onregverdige Diskriminasie 4/2000.

Wet op Nasionale Onderwysbeleid 27/1996. 


\section{Steyn}

Wood-Bodley, M.C. (2007). Freedom of testation and the Bill of Rights: Minister of Education v Syfrets Trust Ltd NO. South African Law Journal, 124(4), 687-702. 